\title{
When robots go wild
}
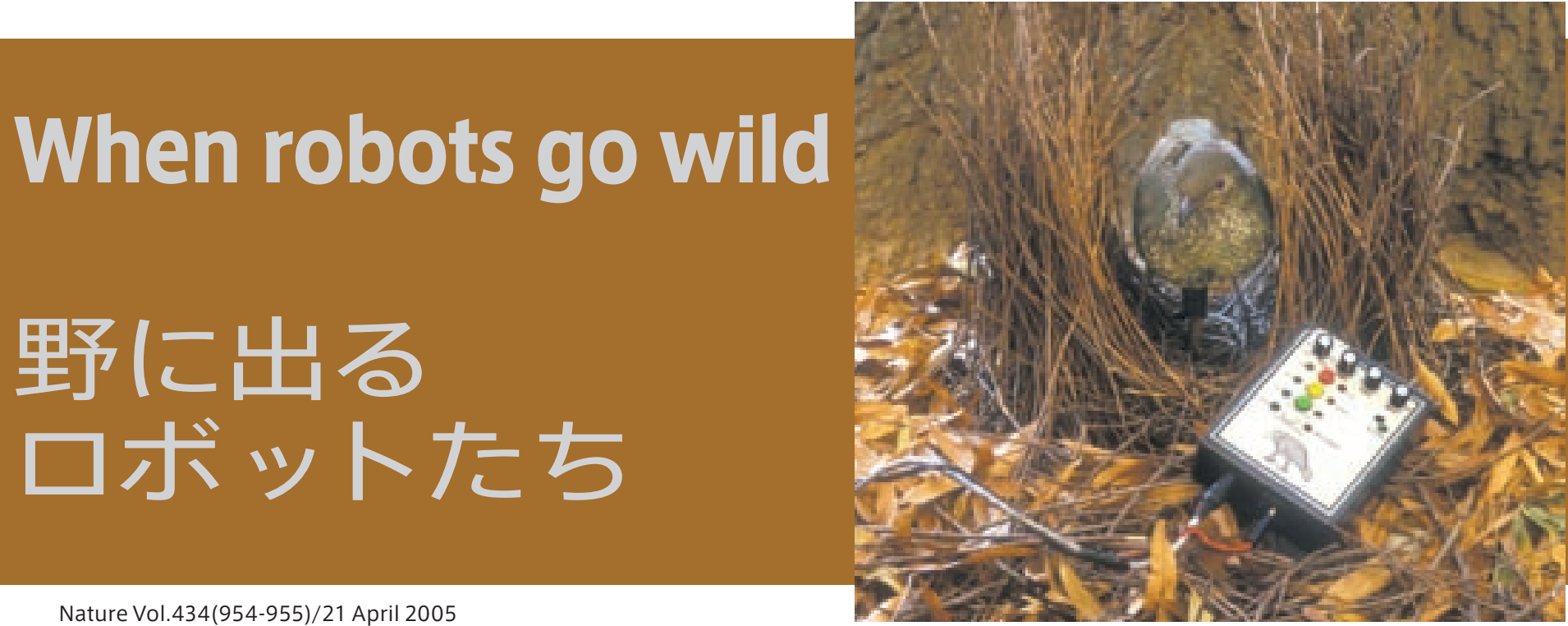

Nature Vol.434(954-955)/21 April 2005

Jonathan Knight

ロボットが研究室を抜け出て野生動物の世界に入り込もうとしている。動物行動を動物型ロボットを使って調べる研究 が盛んになってきたのだ。生物の振る舞いを決めているのは何なのか。この問題の解明に、動物口ボットがどのよう に役立っているかを Jonathan Knight が取材した。

米国ワイオミング州の大草原では、今 春もキジオライチョウ (Centrocercus urophasianus）が交尾相手を見つけ ようと集まっているはずだ。しかし、 メスを意識しながら誇らしげに気取っ て歩くオスのうち何羽かはきっと面喰 うことになるだろう。オスたちが交尾 に誘おうとするメスのうちの 1 羽は機 械仕掛けのにせもので、鉄道模型の線 路の上を走り回っているのだ。

行動生物学者 Gail Patricelli は 10 メートルほど離れたやぶの中にうずく まって、鳥口ボットの動きを遠隔操作で 操っている予定だ。事態が手におえな くなった場合に備えて、彼女は口ボット を救う準備もしている。「最悪のシナリ オは、ロボットが脱線してしまってオス に引き裂かれるか、ワシが舞い降りて 襲いかかり、持って行ってしまうこと」 とPatricelli は言う。そうなってしま えば彼女が数力月を費やして準備した 実験が突然終わってしまうことになる。

Patricelli はカリフォルニア大学デー
ビス校の助教授で、機械工学に明るく、 行動生物学にロボット工学を応用する手 法をいち早く取り入れた生物学者のひ とりだ。無線送信機やコンピューター チップ、デジタルカメラ、音声録音機が 小さく、安くなったおかげで、研究費 が乏しい若手研究者でも自作ロボットに 手が届くようになった。

その結果、以前は検証が難しかった 動物行動学の仮説を試す実験に、リス からロブスターにまでいたるロボットが 使われるようになった。マクォーリー大 学（オーストラリア · シドニー）の動物 行動学者Christopher Evans は「口 ボットは動物行動学研究に新しい手法を もたらした。私たちはこのようなテクノ ロジーに飛びついて、『この実験ができ るようになるのを 20 年間待っていた んだ。それがとうとう可能になった』 と喜ぶことがよくあるが、まさにそう いった雰囲気がある」と話す。

動物ロボットの可能性を初めて探っ た研究者の中に、デンマークのオーデ
ンセにある南デンマーク大学の Axel Michelsen がいた。Michelsen は 1990 年代初め、ミツバチのダンスの解 読に使うため、機械で制御され、ろう でコーティングされた真ちゅう製のミツ バチを製作した。ミッバチのダンスは、 巣にいるほかのミツバチに食料の在り かを教えるためのものだ。真ちゅう製 ミツバチは、通常のミツバチよりも少し 大きく、折れたかみそりの刃で作られ た羽根を 1 枚だけ備えていた。このミ ツバチは本物のミツバチによく似ている わけではない。だが都合のよいことに、 ミツバチの巣は真っ暗なのでそれがば れることはない。

ミツバチはダンサーを見ることができ ないため、主にダンサーが作り出すパル ス状の空気の流れによってその動きを 感じとる。Michelsen は、本物のミッ バチが演じるダンスの一部分を人エミッ バチに演じさせてみて、食料への方向 とそこまで距離をダンスでどうやって 伝えるのかを見出した 1 。 


\section{セクシーポーズの研究}

Patricelli は動物ロボットを使う研究 手法に夢中になり、アオアズマヤドリ (Ptilonorhynchus violaceus) の求愛 に関するポスドク研究のために鳥型 ボットを作った。それはかなり単純なも のだった。メスのめいぐるみで、操作レ バーをひねると、うずくまったり、頭を 回したり、羽根をふくらませたりする ことができた。それでも本物のオス鳥 にとっては、まったくにせものには思え ない出来だったようだ。Patricelli は、 オスはディスプレイ（誇示行動）の激し さをメスの合図に応じて加減すること を発見した。メスが受け入れるように 見えると大げさにディスプレイを行い、 メスが冷淡だとディスプレイをトーンダ ウンさせるのだ 2

このアオアズマヤドリロボットは、 Patricelli がもっと精巧なキジオライ チョウロボットを製作したため、今は引 退して段ボール箱におさまっている。 新型口ボットは無線操縦で方向を変え、 オスにとって挑発的なうずくまる動き をするだけでなく、オスの反応をとら えるためビデオ撮影と録音を行う装置 も備えている。

実験のポイントは、キジオライチョウ の交尾のシグナルを監視することだ。 「外部から単に観察しているだけの場合、 鳥どうしの会話をときほぐすのは難し い。しかし、鳥の一方を操縦している 場合は、そこで何が起きているかがよ りよく分かる」とPatricelli は話す。 キジオライチョウはレックの中で交尾す る。レックはオスが求愛のために集まる 開けた場所で、そこでオスは誇らしげ に歩き回り、羽根をディスプレイし、胸 の喉囊から太鼓をたたくような大きな 音を出す。ロボットは本物のメスのよ うにレックを歩き回り、さまざまなオ

スを「観察」し、体の 後ろの部分を動かすこ とによってオスへの興 味を表す。Patricelli は、オスにとってメス のどの動きがもっとも 刺激的で、それにオス がどう反応するかを 知りたいと考えてい る。

鳥の場合、ロボット に自然な動きをさせる のはわりと簡単だ。鳥

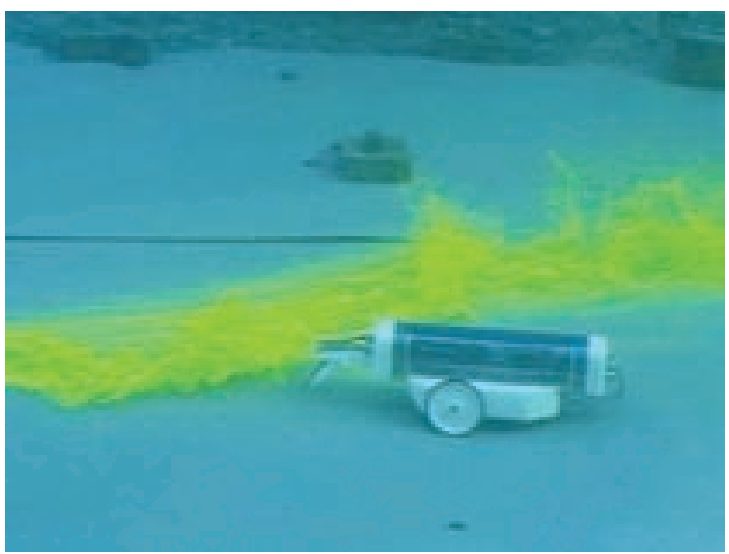

鼻を使って : ロブスターロボットは獲物へ近づくために、にお いのプルームを追いかける。
の動きはもとから少し

ぎくしゃくしていて、元々が口ボットの ようだからだ。Patricelli の作ったキジ オライチョウはかなりスムーズな動きを するが、それが必ずしもポイントとなる わけではない。というのも、動物は同じ 種の動物を見分けるとき、きわめて限 られた刺激に反応するらしいからだ。 たとえば、Evans とマクォーリー大学 の同僚 Ann Goth は昨年、卵からかえっ たばかりのヤブッカツクリ (Alectura lathami) が同じ巣の仲間を見つける のにどんな手がかりを探すのかを見つ けるため、ひなのロボットのシリーズを 作った。ロボットはみな同じように見え るが、注目を一手に集めたのは、狩猟鳥 によくみられる、ぎくしゃくしたつい ばむ動作をするものだっだ。

ロボットは、異なる種の間のコミュニ ケーション研究にも役立つことが分 かってきた。Patricelli の研究室から 大学のキャンパスを横切ったところに、 数十匹のガラガラへビ (Crotalus viridis）を飼育している部屋があり、 このへビは大学院生 Aaron Rundus がつくったロボットリスと定期的に遭遇 することになっている。

カリフォルニアジリス (Spermo- philus beecheyi) はガラガラへビの 好物だが、いつでも簡単に捕らえられ るというわけではない。おとなのリス はへビの毒に抵抗力を持つのできわめ て大胆で、尻尾をフロントガラスのワイ パーのように振るなどの攻撃的なディス プレイをしてへビを追い払うこともよく ある。

このディスプレイがユニークなのは、 視覚と赤外線の両方の刺激を使ってい るらしいことだ。ガラガラへビは熱に非 常に敏感なので、リスは尾を振るとき、 尾の温度を $2^{\circ} \mathrm{C}$ 上げる。Rundus は 昨年6月、メキシコのオアハカでの動物 行動学会年会で、同じリスが熱に鈍感 なゴーファーヘビ (Pituophis melanoleucus）に尾を振るときには、尾の 温度を上げないらしいことを報告した。

ガラガラへビの反応が熱のシグナル にどれだけ影響されるかを調べるた め、Rundus はデービス校の機械工学 者 Sanjay Joshi と協力し、ぬいぐるみ のリスを作った。このリスの尾はモー ターで動き、温度を上げ下げできる。 Rundusはこの未発表の研究成果につ いて詳しくは話したがらなかったが、実 験はうまくいっていることをほのめか 
している。Rundus によると、重要なの は野生では行えなかった制御された実 験がロボット工学で可能になったこと だ。ガラガラへビに出会っても尾の温 度を上げないようにリスを説得するの は不可能である。「これは行動生物学で 長い間、待ち望まれていたことだ」と Rundus は話す。

\section{ロブスターやゴキブリも}

動物の行動をまねるロボットを作れば、 そのロボットが実際の生き物とのやりと りをしなくても分かることは多い。た とえば、ニューヨーク市立大学ブルック リン校生体模做技術・認識ロボット工学 研究室の Frank Grasso 室長は、水の 中のにおいのついたプルームを追いか けるロブスター（ウミザリガニ）ロボッ 卜を作り、ロブスターが獲物をどうやっ て見つけ出すのかを研究した。「このロ ボットのおかげで、以前からあった仮説 をより正確なものにすることが可能に なった」と Grasso は話す。

ロブスターは、においの濃度の高い方 向へ泳ぐことで獲物を探し出すと考え られていた。しかし、室内での実験では、 この原則だけで動くロブスターロボット は、特に獲物から離れているとき、う まく獲物を探し出すことができなかっ た。Grassoらは、これは水中のにお いの勾配を乱流があいまいにするため かもしれないと考え、ロボットに流れを 感知することができるセンサーをつけ、 においは上流から来ると仮定させるこ とにした。この改良ロボットは、本物の ロブスターとよく似た動きをした 4 。

しかし、それでもロブスターロボット が自然界のロブスターとまったく同じ ように振る舞うわけではない。Grasso は、たとえばにおいのプルームを見失っ たときのために記憶アルゴリズムをつ
け加えるなど、 ロボットの改良 を続けた。「ロ ボットのおかげ で、ロブスター の脳の中で何 が起こってい るかのモデル を一歩ずつ組 み立てること が可能になっ た」と Grasso は話す。

この研究方法には限界もある。本物 とにせもののロブスターが同じような動 きをしたとしても、そのロボットのアル ゴリズムとロブスターの脳が同じように 意思決定していることを実験で直接確 かめることはできない。しかし、心理 学者の Jeffrey Schank は「ロボットを 使った研究では少なくとも、『最低限の 行動原理』を探ることはできる」と話す。 Schank はJoshi とともに単純な行動 規則に従うラットロボットを作る研究を 行っている。「ラットの行動をまねるロ ボットを作ることができたら、それは ラットを理解する第一歩となる」と Joshi は説明する。

このラットロボットは完全に自律的 に行動し、脳であるコンピューターに プログラムされた確率アルゴリズムと、 どのセンサーが活性化されているかに もとづいて、行き先の意思決定をする5。 Schankにとって重要な問題は、「脳が しなければならないことは最低限どれ だけか?」ということだ。「私たちは、 特定の行動にとって必要な認識能力の 最低レベルを明らかにしようとしてい るのです」とSchank は話す。それが 分かれば、動物が自然界でどのように 行動しているかの仮説にフィードバック news feature

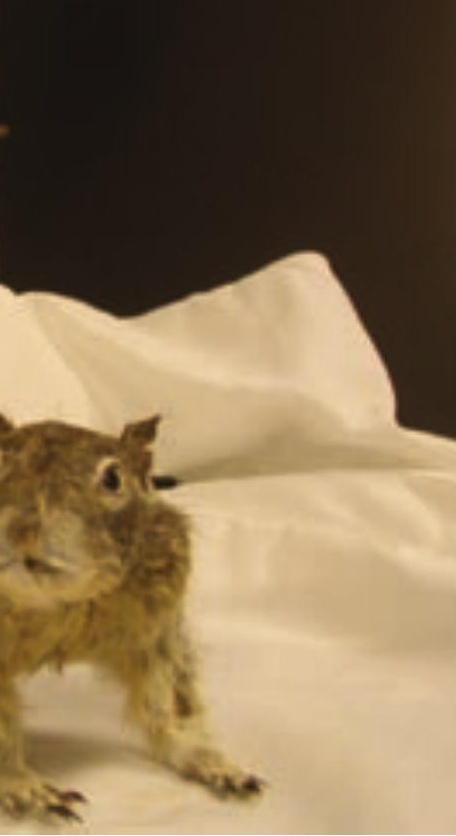

することができる。

ロボットを使った研究はまだ始まっ たばかりだ。 1 対 1 の相互作用だけで なく、集団行動を調べている研究者も いる。ブリュッセル自由大学の JeanLouis Deneubourg ら欧州の研究者 チームは、生きているゴキブリの集団 と相互作用できるゴキブリロボットを 作った。彼らはゴキブリロボットを使っ て、安全な隠れ場所を選ぶなどの集団 の意思決定の仕組みを解明しようとし ている。

本能的に集団で働くという行動は、 どうやらさらに多くの動物行動学研究 者にロボットを使わせることになるかも しれない。Patricelli は「この方法は流 行しているみたいで、会議に行くたび に、ロボットを使う研究者が増えている のを耳にします」と話した。

Jonathan Knight（サンフランシスコ）

1. Michelsen, A., Andersen, B. B., Storm, J., Kirchner, W. H. \& Lindauer, M. Behav. Ecol. Sociobiol. 30, 143150 (1992)

2. Patricelli, G. L., Uy, J. A. C., Walsh, G. \& Borgia, G. Nature 415, 279-280 (2002).

3. Göth, A. \& Evans, C. S. J. Exp. Biol. 207, 2199-2208 (2004).

4. Grasso, F. W. Biol. Bull. 200, 160-168 (2001).

5. Schank, J. C., May, C. J., Tran, J. T. \& Joshi, S. S. Adap. Behav. 12, 161-173 (2004). 